\title{
THE GREAT MASTERPIECE
}

\section{The Rök stone and its maker}

Ola Kyhlberg

\begin{abstract}
The author attempts a source critical and semantic revision of the traditional reading of the concluding lines 25 to 28 on the Rök stone in the province of Östergötland (Ög I 36). Guided by the placement of these lines in the text's narrative, the author tests the hypothesis that the writer's signature may be included in this sequence. Indeed, if this is the case, Sibbe is the master of the Rök stone, not Varin, and the giant mentioned in the text presumably alludes to the rune stone itself. The original place of the monument is also discussed in connection with the place-name Jättingstad.
\end{abstract}

Key words: the Rök stone, new interpretations, runemaster, lawspeaker, melodious recital

\section{INTRODUCTION}

The Rök stone (Ög I 36) is undoubtedly a remarkable monument, but above all it is a work of masterly skill. For centuries this rune stone has evoked the curiosity of people and been a scientific challenge to researchers. The inscription's literary content, linguistic form and syntax have all been studied astutely.

Gun Widmark has said that the initiator of the inscription must have been a key cultural personage, but in that case for whom was the stone created? Perhaps Varin did not carve this inscription for any particular reader but saw in the stone a kind of "robot" that could magically take his place and assume the role that had been his own (Widmark I997:I65f). Widmark emphasizes that it is symptomatic that the text's interpreters have reached widely differing conclusions in their respective holistic views of the text. While one scholar has read it as a legal 


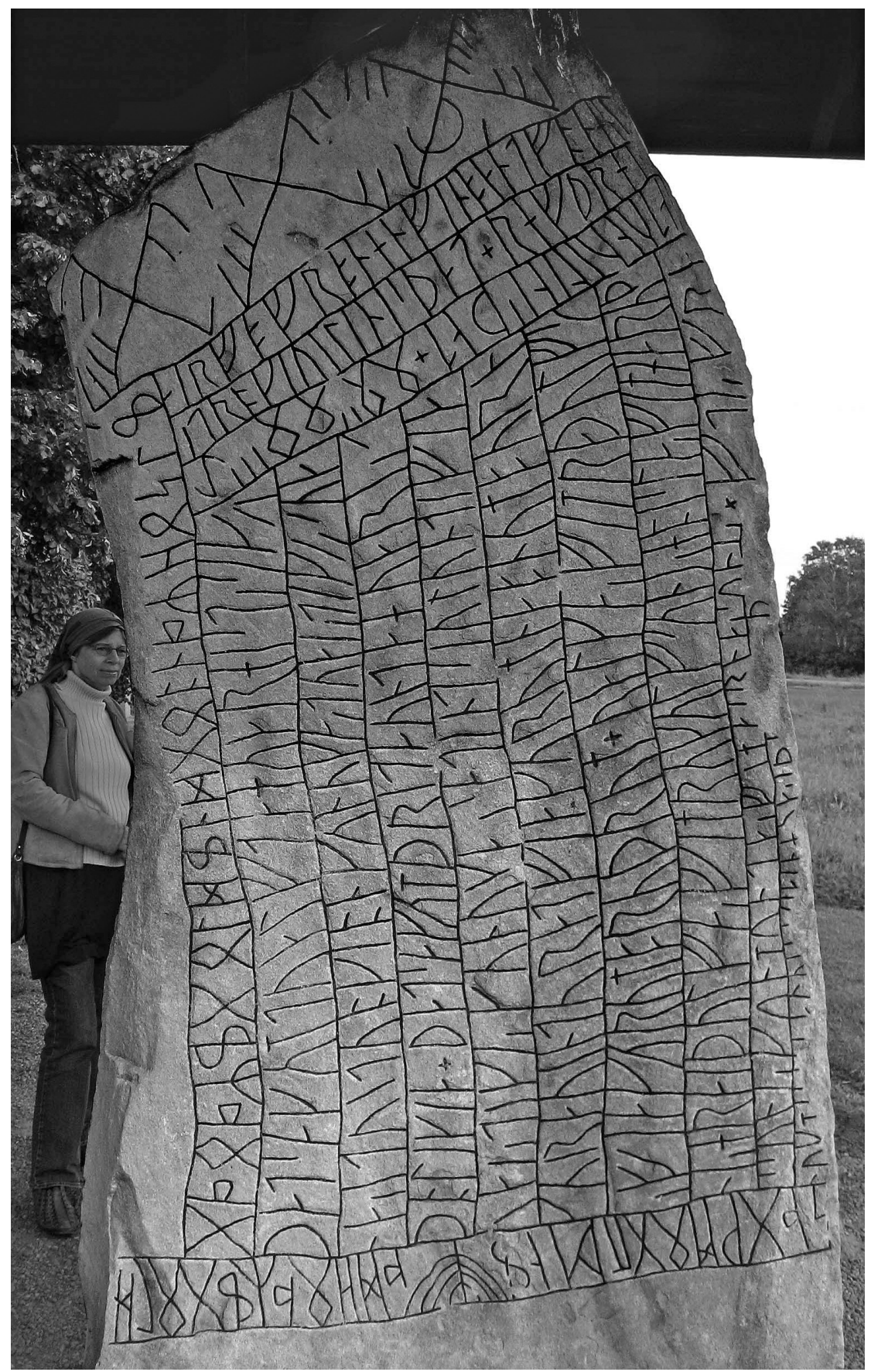

Fig I. The rune stone at Rök Church, Lysing hundred in Östergötland (Ög I 36). Photograph and computer revision by David Bruno. 
document, another has understood it as sprung from a genealogical poem and still others have basically seen it as a so-called greppaminne, constructed as a sequence of questions and answers (von Friesen I907; Wessén 1958; Lönnroth I977:77ff; Gustavson I991; Widmark I993, I997:I70; Grønvik 2003; Arwill-Nordbladh 2007).

A scholar who has recently addressed the complex problem of interpreting the inscription is Bo Ralph. He states that contemporary researchers generally agree on the reading of the individual runic letters and that the main discussion concerns the text's deeper meaning. He points out contradictions, questions elaborate explanations and, on certain points, also the text's wording and meaning (Ralph 2007:I23f, I $34 \mathrm{ff}$ ).

A number of specific problems and questions are discussed in this paper, such as:

- Who was actually the maker of the stone and its inscription?

- Who or what was in fact the giant mentioned in the text?

- What mode of presentation could be imagined for the Rök stone's epic?

- What was the original place of the monument?

\section{THE SCALDS}

In an early article, Otto von Friesen has given the following inspired characterization of the maker of the Rök stone (von Friesen I 907:I 5; Andersson 2006:3):

... with proud self-esteem has shown ... the depth and extensive knowledge he had in ancient and contemporary runic composition ... He has ... wanted to give an overview of the many ancient poems and tales he had in his repertoire. He was a scald, in the original meaning of this word: teller of tales and reciter.

The poem Beowulf includes the characterization of a prominent scald (Beowulf: A Verse Translation, I973: verses 868-874, p. 78):

... whose head was a storehouse of the storied verse, whose tongue gave gold to the language of the treasured repertory, wrought a new lay made in the measure. The man struck up, found the phrase, framed rightly the deed of Beowulf, drove the tale, rang wordchanges 
In early research the Iron Age scald was often seen as a kind of poet of temporary nature, but in the scald's activities lay the task of a historian of considerably higher dignity.

In Olav den heliges saga, Olav Haraldsson ( $\mathrm{d}$. AD I030) tells that a couple of the king's Islandic scalds, his court poets, often sat on a bench across from the king in the great hall and spoke freely but not without respect. This seating was considered the most honorable, above all during drinking ceremonies. That the explanation behind the social self-image of the scalds lay in their task as historian and chronicler can be understood from the story of the Battle of Stiklastad in the same saga (Heimskringla. Transl. with introduction and notes by L.M. Hollander, 1964:496):

... when King Olav had rallied his men, he assigned men to create a protective shield that would surround him during the battle ... He then called for his scalds and said to them ... "You must be here to see what happens ... In that way it will not be others who will tell tales and write poetry about it later."

More advanced scalds possessed a linguistic and literary dexterity whose esthetics can be compared to the high level of metalworking during the period. In his iconographic study of rune stones, Anders Andrén has pointed out that the art historian Sven Söderberg, already a century ago, in reference to Háttatal, argued that poetry and animal art were analogous (Snorre's Edda ... I95 8:22ff; Söderberg I905; Andrén 2000:II, 26):

The similarity between animal art and scaldic poetry instead speaks in favour of some kind of relevance for the different styles. They can be regarded as visual stanzas or visual metres by analogy with the metric forms of scaldic poetry that are described by Snorri in his Háttatal.

It is very clear from Háttatal that it was a literary virtue, formally as well as with respect to syntax and semantics, to create ambiguities and diversities. Háttatal is introduced with a description of the kind of verse known as drottkvatt 'court meter', followed by a description of the scaldic poetic style and of the distinction between stuðningar 'supporting or specifying first element in a true kenning', kenningar 'kennings', sannkenningar 'true kennings', and nygörningar, nýgervingar 'new creations'. 
Thereafter follow the important metrical and other liberties, leyfi, including the following nine (Snorre's Edda ... I95 8:2ff; see Meissner I92I after Ralph 2007:I33):

- enjambment álag

- whole assonance instead of half-assonance in odd lines

- combination of two syllables to one

- change in tense in a half-strophe

- two words with assonance beginning with the same consonant

- repetition of the same expression in both of the strophe halves

- repetition of verses or part of a verse

- repetition of small words in the same half-strophe that can cause obscurity or misunderstanding

- inclusion of parentheses that break up the phrase context

Although researchers have had great respect for the Rök stone's scald, the consequences of this do not seem to have been considered by formulating concrete expectations or hypotheses concerning the possible appearance of literary-poetic artistic tricks. Against the background of the poetic rule of Háttatal, it could be expected that certain choices of words were steered by poetic demands, such as assonance, alliteration, rhythm, intonation and melody, more than by the narrative's demands for semantic clarity (Björn Collinder's introduction to Snorre's Edda ... I 958:23). Poetic elegance may thus have been chosen before semantic clarity, but in research semantics seems to have taken a back seat to accidence and syntax, and semiotics is overshadowed by iconology.

\section{STRUCTURE OF THE TEXT}

The maker of the monument, its gorningisman - a term used in early provincial Swedish laws for craftsman, but appearing in the Icelandic literature as gerningamað $r$ for magician/sorcerer/wizard - was a bearer of literary tradition on the highest level. The "flowing hand" of his work consequently shows that he knew how to use the majority of different literary or poetic rules and artistic tricks (Jansson 1977:32ff; Ralph 2007:I24f and references cited therein; Arwill-Nordbladh 2007:58). Both a 24-rune futhark and a I6-rune futhark, as well as short-twig runes (Sw. kortkvistrunor), numerical ciphers (Sw. talchiffer), cryptic transpositional ciphers (Sw. förskjutningschiffer) and secret runes (Sw. lönnrunor), in addition to riddles and other kinds of illusionism 


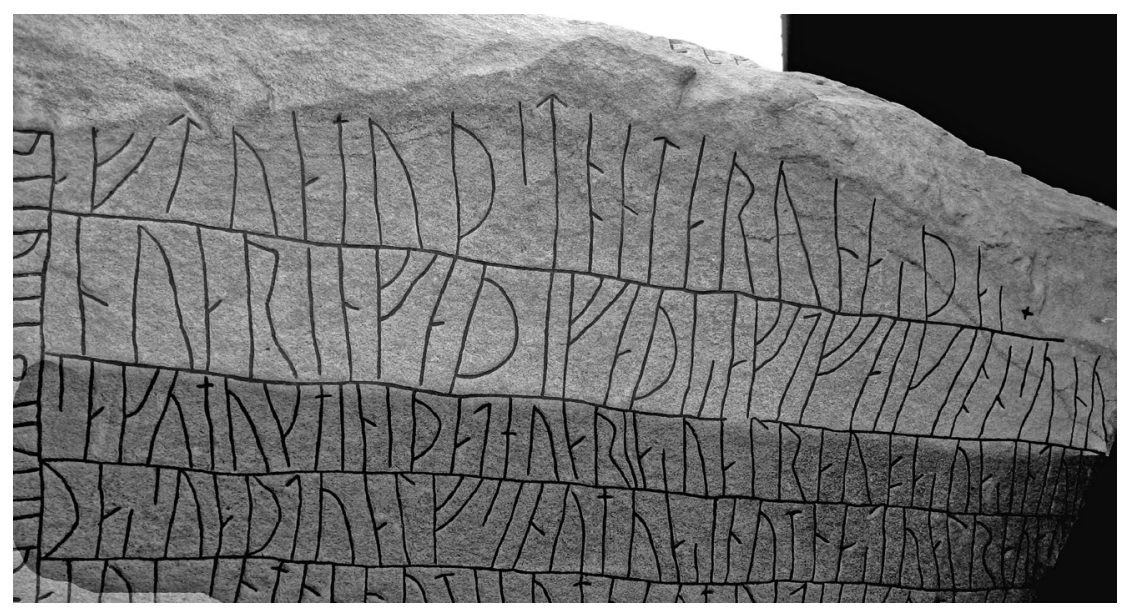

Fig 2. The Rök stone's dedication.

Photograph by David Bruno.

including what is probably an anagram, were all part of his "tool kit".

He excelled in his command of the carved rock faces in an architectural spirit, and he carved the inscription with nearly calligraphic ambition. Nothing seems to have been left to chance, and there are few clear mistakes, if any.

The text can be divided into three, mutually distinctive sections. The first section $(\mathrm{A})$ is the short introductory dedication including lines I and 2. This is followed by the sizeable epic and mystical main section (B) including lines 3 to 25 . The third and closing section $(\mathrm{C})$ includes lines 25 through 28 , beginning with the reference to the poet/rune-master in line 25 (Gustavson I99I:2 Iff). Thorsten Andersson has reflected on the size of the runes in the dedication, where the text band is approximately 25 to $30 \%$ taller/wider than average, something which he deems as linguistically meaningful and comparable to the dominating position of the secret runes on the back face of the stone (Andersson 2006 and below).

\section{Text section A}

Lines I and 2 compose the introductory phrase with the dedication to Vämod, formulated as if it were in the words of Varin, the father (Jansson I987:I32; Gustavson I99I:I4ff):

... Aft Vamod standa runaR paR. Æn Varinn faði, faðiR, aft faigjan sunu ... 
(In memory of Vämod stand these runes. And Varin wrote them, the father, in memory of his dead son)

The dedication has always been interpreted as that Varin was the rune carver. This is probably partly because there has been no evaluation of to what degree the choice of words in these lines can have been steered by poetic demands.

The basic form of the verb faði is fa meaning to paint, write/work/ make, cut. Hávamál mentions runes “... made by mighty gods, known to holy hosts, and dyed deep red by Óthin ... runes and powerful signs ... which that dyed the dread god ..." and "thus I write and the runes I stain ..." (The Poetic Edda. English transl. by L. M. Hollander, I 962:26ff). In these citations the coloring of the runic letters is partly linked to "Óðin", partly to "the dread god" and partly to the "powers". Thus a distinction is made between the verbs dye/stain, make, and write with a powerful reference to the divine aspect of the runes themselves as well as to the knowledge of runes (Den poetiska Eddan ... I972:61, 70, 72; Jansson I977:I 59ff and references cited therein). It probably can be understood that the meaning of the verb fa can not be translated automatically as 'cut', and the coloring of runic letters and signs has had particular magical meaning which is something other than the magic of the cutting and carving itself.

The stem of the word faigjan also appears in Guta Saga in the sentence "Mik witin ir nu faigastan oc fallastan", in which a man tells how he fears for his life, going as a negotiator to the king of the Svear (Holmbäck \& Wessén I979:292, 306; Photo in Kyhlberg I99I:I23).

The new reading and interpretation of the concluding text section $\mathrm{C}$, as presented below, is also indirectly important to the interpretation of these introductory lines.

\section{Text section $B$}

Line 3 through letter 6 of line 24 . Following the introduction, the monument itself takes on the role of narrator in the verb sagu(m) which has the fundamental meaning of saga 'tell' and which semantically is closely related to the concept of saga in such words as domsaga 'judicial circuit' (Wessén 1958:76; Widmark 1997:I67ff and references cited therein).

This form of ingress is probably comparable to the formulation in Voluspá, "I ask for hearing from all", which also appears in the Icelandic sagas when someone wishes to perform a recitation or song (The 
Poetic Edda ... Ed. by Ursula Dronke 1997:7; Gustavson I99I:2 Iff). This is discussed below.

In addition, this text section mainly includes parts of narratives that possibly may be explained as excerpts from an original erfidrápa or erfikvoeði. The scalds' presentations of such elegiac memorial poems seem more or less to have been an institutionalized part of the burial ceremony erfi (Heimskringla. Transl. with introduction and notes by L.M. Hollander, I964:I24f; Hallberg I993:5 If; Sävborg I997:I77, note 2 I 5; Sundqvist 2002a: I 70ff, 276f, note I 22).

\section{Text section $C$}

The part extending from letter 7 of line 24 through line 28 has been deciphered and interpreted in widely diverging ways.

Its traditional reading, characterized by Widmark as speculative and linguistically not particularly convincing, is (Jansson I987:34; Gustavson I991:23; Widmark I997:I68ff):

... uilin is pat. knua knatti/i/atun. uilin is pat. nit. sagu $/ \mathrm{m} / \mathrm{mug}$ minni. porr. sibi uiauari ul nirupr ...

The alliteration, assonance and swaying iambic intonation of the text all throw light on the poetic qualities of the text, but simultaneously somewhat hide its meaning, which was an intentional poetic effect according to Háttatal, see below.

Already in lines 2I-22 in the sequence ... hvar Inguldinga vari guldinn ..., the scald's brilliance is declared (Wessén 1958:25; Andersson 2006:I; Ralph 2007:I25). Regarding assonance and alliteration in the sequence ... knua knatti/i/atun ..., the title of a modern children's film, "Klaga lagom Alfons Å berg" ("Happy Alfie Atkins") by Gunilla Bergström may be offered as an analogy, representing a living poetic practice.

\section{Reading order}

The different categories of letters and signs are principally kept together, with one exception: the last letter of line 25 , a single secret rune (Sw. lönnruna) of the kind found in I9 instances in the following line 26. Since the scald otherwise does not mix short-twig runes, numerical ciphers, cryptic transpositional ciphers and secret runes, this isolated instance undoubtedly must be understood as a practical instruction to the reader! Without this support it would be very difficult to identify 
the continuation of the text on the narrow side of the stone. This single secret rune should most probably be linked to its typologically comparable letters in line 26 on the narrow side of the stone, which thus should be read from the base of the monument upwards.

In consequence the traditional reading order must be changed, and therefore also the reading. This means that the secret runes should be read as III $/ 3 /$ not III/ $/ 2 /, \mathrm{III} / 3$ and III/ $/ 5$, which are the runes $\mathrm{b} \mathbf{p}$ and $\mathrm{R}$, respectively. Combined with ni in line 25 , this seems to become ... nippR (?) This doubling of the runic letter $\mathbf{b}$ may perhaps be explained as the result of some kind of confusion ( $c f$. Lagman I989:33f).

\section{"HE COULD CRUSH A GIANT" (?)}

The traditional interpretation of the sequence ... / uilin is pat/knua $\mathrm{knatti} / \mathrm{i} /$ atun/uilin is pat/... in lines 24 and 25 has become, in romantic spirit, approximately "he could crush/beat a giant /to death/". In contrast Joseph Harris maintained, similarly to Lars Lönnroth, that iatun 'the giant' was the subject and consequently it meant that a giant had killed a man named Vilinn/vélinn. These interpretations are somewhat problematic, as is Widmark's interpretation that the verb knua expresses the giant's sexual activity and not Thor's rough treatment of him with his fists (Widmark 1993:32; Harris 2007:82 after Elmevik 2008:I 7 f).

The word iatun begins line 25 and is written with common runic letters, while ... knua knatti ... at the end of line 24 , the preceding line, is written with transpositional ciphers. This sequence crowns the work, both literally and figuratively, and is situated in a place at the end of the text where it is common in Viking Age runic inscriptions to find the carver's signature.

A key to a new reading of the text could be if one works from the idea that the word iatun should not be understood naturalistically in the sense of referring to just any mystical giant, but instead understood as being a heiti for the monument itself, the giant stone! Besides, in lines I 2-I 3 a heiti also appears in the phrase "where the horse of Gunn (i.e. steed of the Valkyrie, the wolf) sees food on the battlefield" (Jansson I987:33; Gustavson I991:25).

As a consequence of such a reinterpretation there could also be a minor change in the meaning of the verb knua. It still should be understood as firm and powerful, but not to 'crush/beat someone to death', but to 'crush/beat', 'slash out at something'. The verb knua stems from 
the Old West Norse noun knúi, Old Swedish knôe 'knoge', to which the Swedish and Norwegian verb knusa and the Danish knuse 'break apart', 'crush' also belong. In an article from 2008, Lennart Elmevik cites Norrøn ordbok, partly regarding the Old West Norse, Icelandic term knoka 'hit with one's knuckles' and partly concerning the Old West Norse, Icelandic term knosa, etc. (Elmevik 2008:20). Such a meaning of the verb in the Rök stone's text is not possible to establish using any direct parallel, but this suggestion of a new interpretation is supported partly by the close relationship to the modern noun ' $k n o g e$ ' and partly by the fact that mystification, according to Háttatal, had poetic value in its own right.

The overall result of this is that it is not Varin at all who has written the runes and created the monument at Rök, but instead Sibbe!

\section{"VILIN IS PAT" (?)}

Flanking the words ... knua knatti/i/atun ... in lines 24 and 25 is the consequently doubled wording of ... uilin is pat ... Earlier, this has been understood as somewhat disconnected and without clear context, but considering the background of the "craftsman/sorcerer's profile" and with regard to its placement in the concluding text section $\mathrm{C}$ it could be taken as being included in the signature of the writer.

The word uilin traditionally has been interpreted as a heiti for the god Oden, as the name of an unknown (!) son of the god Thor, or as the phrase "Do you wish". Widmark disagrees with Elias Wessén's reading "Vilen it is" and argues instead that it should be read as "Vilen he is", which idiomatically may be expressed as "He is Vilen". It may be noted that Wessén, according to Widmark, probably rejected the last alternative because he had difficulty putting it into a reasonable context (Wessén 1958; Widmark 1997:I68f; Sundqvist 2002a:I64).

Recently, Elmevik published an article where he presented convincing arguments in support of the idea that uilin should be a man's name, identical with the Old Norse adjective vélinn, Old Swedish *velin 'knowledgeable in magic/sorcery' (Elmevik 2008:20). The name therefore may be understood as a nickname '[one who is] knowledgeable in sorcery', which in this context logically could be understood as 'runemagician' and the whole phrase ... uilin is pat ... as a commentary on Sibbe's great literary brilliance.

The formulation by von Frisen, "The deep and extensive knowledge he had in ancient and contemporary rune usage", should have included 


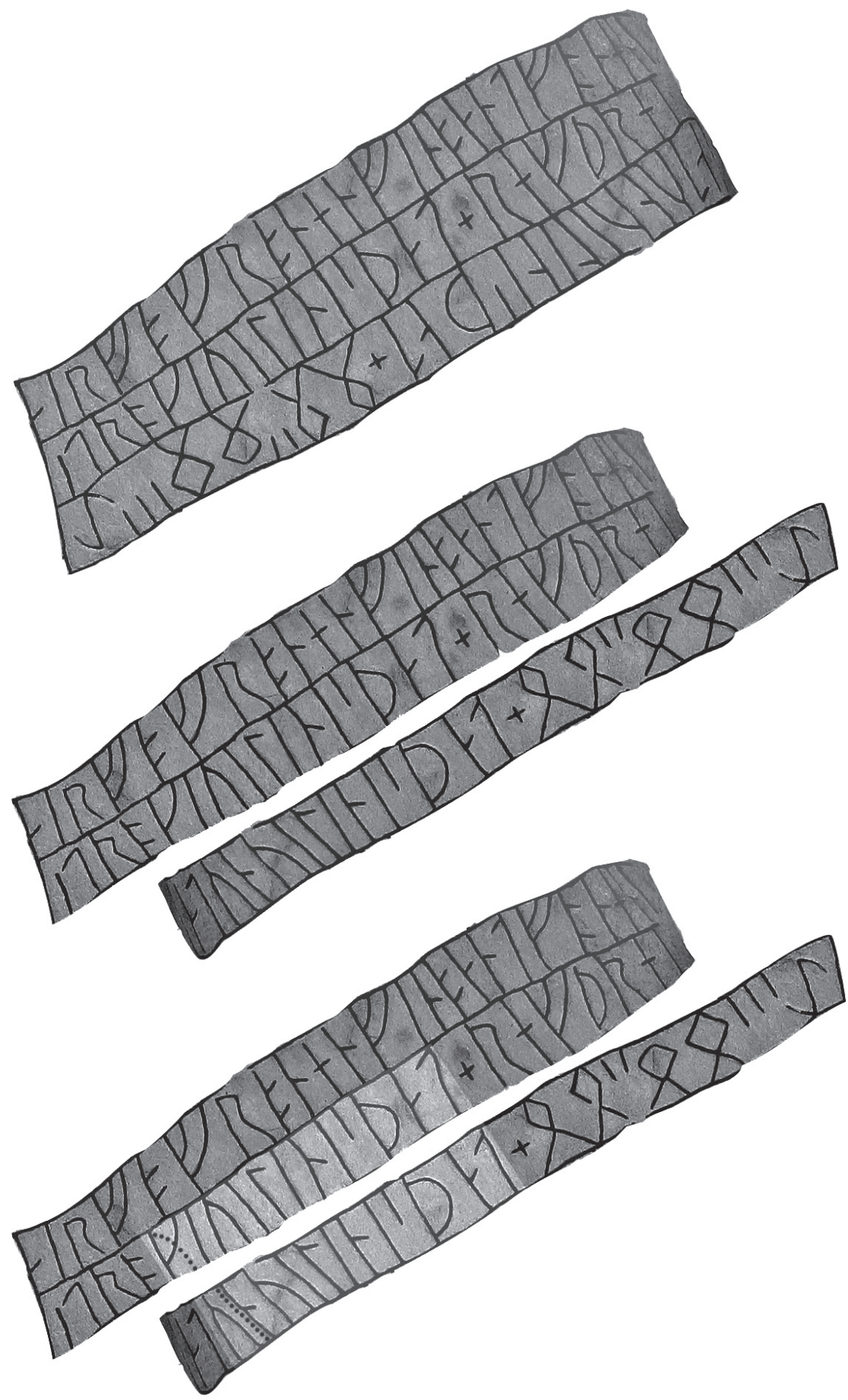

Fig 3 A-C. Lines $23-25$ of the Rök stone along with an analysis and attempt at interpretation. Photograph and computer revision by David Bruno. 
a large measure of magic and sorcery (von Friesen 1907). One may recall the duplicity in the meaning of gerningamadr/gcerningisman which in its earlier form in the Icelandic literature meant 'magician/wizard/ sorcerer' and which in its later form in medieval provincial law had been watered down to mean 'craftsman'. Regarding Sibbe's literary dexterity we may take it that he was seen by his contemporaries as a true 'rune-magician' (Price 2002: I I Iff).

\section{*Vivil (?)}

According to Per Vikstrand the term for cult-functionary, "vivil, may be a diminutive form of the word that forms the basis for the personal name WiwaR. It was not borne by any particular chief or leader, but by someone in this person's sphere. (Hellberg I 979:I6I with note 97; Gustavson I99I:20; Vikstrand 200I:393f; Sundqvist 2002a:I64; Palm 2004:35).

The word uilin in the phrase ... knuaknatti/i/atunuilinispat ... associatively may lead one's thoughts to the term for cult-functionary *vivil, but then how should the missing introductory syllable $v i$ - be understood? The answer may lie in poetical freedom where, according to Háttatal, two syllables could be combined to make one. An example of this kind of illusionism is illustrated in how the main syllable of the words aft and $\boldsymbol{x n}$ in lines I and 2, respectively, coincides with the outer line of the vertical text band (see Fig. 2), and ... knatt/i/iatun ... already shares the letter I. In speculation therefore, the missing syllable could have been an attempt to mystify. If only the $\mathbf{n}$ - rune's secondary sign in the word iatun is neglected (painted?), the main letter may be read as an I-rune. Thus, the word "vivil appears. The same word might be read in the previous line if the k-rune in the word troki 'dräng' (follower?) is changed to a u-rune with the help of an imagined (or painted?) line (von Friesen I920:63f). But this is only speculations.

Elisabeth Arwill-Nordbladh has understood the original surface of the stone as being light and clean (Arwill-Nordbladh 2007:59), but the shade of its present color can definitely be compared to the eroded surface of the often whitish-gray antique marble sculptures and architecture or the natural wood of many medieval church sculptures. All of these objects were originally brightly colored.

\section{*VIAVARI}

In a study from 2006, Thorsten Andersson placed great value on the dominating position of the secret writing on the back face of the stone, 
which in his opinion had not been given enough attention (Andersson 2006:2f):

... it may be a secretive message, about the desire to keep secret, excel, entertain, or test the acumen of the reader or perhaps about magic.

As evidence of this foresight, in 2007 Ralph presented an alternative reading and interpretation of the conclusive phrase ... sibi uiauari ul nirupR ... According to him, this sequence is an anagram (Ralph 2007:I4 I with reference to Grønvik 2003)! In this case Sibbe would have constructed an anagram that included his own name and then placed it where it could literally and figuratively crown the entire work!

Using the linguistic demands of the anagram, Ralph's suggestion actually may be able to explain the problem with the duplicated appearance of two such closely formulated epithet/titles as *vivil and *viavari.

Olof Sundqvist has shown that *viavari is semantically comparable to "vés vq̨ðr, "vqrðr vestals 'protector of the temple's altar' which is nothing less than an epithet for the ruler of the Svear in Ynglingatal, along with *vévorpr which appears in other places including, most likely, on the Sparlösa stone in the province of Västergötland. Gustavson compares this linguistically with a medieval Swedish word for churchwarden: kirkioväriande /appr./ (Sundqvist I998; Gustavson I991:I3;Vikstrand 200I:396). In Scandinavian written sources, Norwegian rulers appear as wardens of sanctuaries or holy-mythological places, and in Hákonarmál it is stated in particular that the king is praised for having watched over holy places (Sundqvist 2002a:200, 28I). Vita Ansgarii mentions how Ansgar met a person who claimed to have participated in the holy-mythological congregation that was seen as ruling over the land, and who had now been sent out to spread a message (Boken om Ansgar ... I 986:52f). This cult functionary ought to have been a *viavari.

The inscription on the Oklundahällen stone in Östra Husby parish, Östergötland, mentions a man who had committed a crime (manslaughter?) and then gone to that $v i$ 'sanctuary' where he obviously effected a reconciliation (gained legal immunity?) which was attested by someone named Vi-Finn. A parallel to this name, in the form of $V i$ Gullela, is inscribed on a bowl from the silver hoard from Old Uppsala, dated at the earliest to the late eleventh century AD (Winkler 2008). The still existing Swedish expression varg i veum 'outlawed criminal' bears 
witness to peace and asylum in the sanctuary, and refers to the harshest form of outlawry for anyone who committed an offense against a sanctuary (Vikstrand 200I:324f).

On the Rök stone, it is Sibbe who is linked to the epithet *viavari. Departing from Sundqvist's explanation of the word it is suggested that this refers not only to a cult leader, but also to a position as lawspeaker or judge (Jansson I977:40; Salberger I980:19; Norr 1998:93, I94; Sundqvist 2002a: I96ff with notes, I 59, I96f; Strid 2005: I 5 of, and literature cited therein, $c f$. Widmark I997:I7 If). This would be a completely acceptable explanation to his unique literary competence and literary education as well as his power of creating characters, and it would give a satisfactory answer to Arwill-Nordbladh's key question of how the scald was able to produce such an exquisite written document without any known prototype (Arwill-Nordbladh 2007:59).

As Anders Andrén has mentioned in a seminar, the question of Varin's and Vämod's respective social positions then arises. Supported by the hypothesis that Sibbe was a lawspeaker or judge, Varin should have been a regional sovereign and the monument been initiated by the legitimacy crisis which occurred with the death of his heir, Vämod.

It is probably such a situation that is reflected in the epic part of the inscription. In text section B, the speaker,pulen (?), turns to the family myths, that is, the forefathers, which ought to be an expression of legitimacy.

\section{"NINETY-YEAR OLD BEGOT" (?)}

The word nirupR 'ninety-year-old' actualizes the question of praxis regarding the designation of age. According to Andreas Nordberg, an inclusive way of calculating was used in ancient times, and Göran Henriksson has opposed the interpretation 'every ninth year' in the expression post novem annos since the first year is reckoned from the first day of the year and not from the last as is done today (Henriksson I995:34I; Nordberg 2006; Sundqvist 2007:I39; note I4O). Consequently, a word such as nirupR should be understood as if, in fact, Sibbe was in his eighties, not his nineties ( $c$ f. Wessén I95 8:54; Andersson 2006: I, 5f; Arwill-Nordbladh 2007:59). A person can be expected to be considerably more vital at 80 than at 90 years of age.

The verb ala /el, ól, alinn/ in ... sibi uiauari ui nirupR ... in line (27-) 28 in text section $\mathrm{C}$ traditionally has been read as avla 'beget'. Some researchers thereby have taken the liberty of supplying the noun 'a son': "Sibbe of Vi, ninety years of age, begot /a son" (Jansson I987:36), a 
speculation which is not reasonable with regard to the narrative's precision in other respects.

A shift in meaning of the verb ala may be the key to a reinterpretation.

In Old West Norse the verb ala meant avla 'beget, father' and föda 'give birth, mother', föda till världen 'bring into the world', föda och uppföda 'give birth and nourish'. In poetic language the verb has the additional meaning of 'being animated or ruled by' (Jónsson, F. (Ed.) I93 I:5; Fritzner I883-96/I954/:26ff). In medieval prose the verb still had similar meanings: avla, föda, föda upp, upprätthålla 'beget, give birth, nourish, maintain' and utöva något över någon 'exercise something over someone' (Ordbog over det norrøne prosasprog I, I 995:spalt 250-252). Judging from the context, the scald's use of the particular verb ala probably should be understood as having been intentionally chosen for its obvious, powerful, fundamental meaning of avla, föda, so as to confidently say that by this action, inscription and narrative he gave life to this giant stone. The hypothetical question then is whether or not the verb's basic meaning could be taken as semantically close to the verb koncipiera, befrukta, fá idé till 'conceive, inspire/ stimulate, have an idea for' (Nationalencyklopedien, Bd I I, I 993:228).

In the framework of the 'craftsman's profile' as sketched above, it would seem to be completely natural that, in his contemporary and social environment, the surely greatly respected and highly esteemed Sibbe wanted to point out, not least to future generations, that despite his considerable age he was able to carve and form this giant block of rock, and in doing so he created this remarkable written monument.

A main result of this study is the following suggestion for a revised reading and idiomatic interpretation of text section C (cf. Gustavson I99I):

\begin{tabular}{|c|c|c|}
\hline Inscription & Prevalent translation & Idiomatic interpretation \\
\hline ... uilin is pat & Vilen is it & "The rune-magician" is it \\
\hline knua knatti/i/atun & He could crush a giant & He could carve the giant /stone/ \\
\hline uilin is pat & Vilen is it & "The rune-magician" is it \\
\hline sagu/m/mugminni & $\begin{array}{l}\text { We tell the kinsmen's tale/ } \\
\text { I tell the young ones }\end{array}$ & $\begin{array}{l}\text { I tell the young ones/ } \\
\text { I tell the ancient tale }\end{array}$ \\
\hline (?nip/b/R?) & (TOR. Nit) & \\
\hline sibi uiauari & $\begin{array}{l}\text { Sibbe } \\
\text { watchman of the sanctuary }\end{array}$ & $\begin{array}{l}\text { Sibbe } \\
\text { watchman of the sanctuaries }\end{array}$ \\
\hline ul nirupr ... & $\begin{array}{l}\text { ninety years of age } \\
\text { begot [a son] }\end{array}$ & $\begin{array}{l}\text { eighty years of age } \\
\text { created }\end{array}$ \\
\hline
\end{tabular}




\section{MODE OF PRESENTATION}

What mode of presentation could be imagined for the Rök stone's epic: story-telling, speech or recitation, or something else?

Similarly to Stefan Brink, Sundqvist gives a picture of the scald who recites in the hall, pointing out that the poetry, with respect to the semantics in the word $p u l$, should have been presented in a kind of mumbling voice. Etymologically, Brink combines the word $p u l$ with 'speak', 'ramble' (rhymes), and probably also 'sing' (Brink 2003:79; Sundqvist 2002a:2 Iof; 2007:35f). To a certain extent, such a conclusion may be analogized with Britt Solli's idea about a connection between pulen and the Sami naid 'shaman' since the latter, among other things, is presented as being both a notable story-teller and a speaker-singer (Price 2002:259f; Solli 2004:263,27I).

Widmark and others have pointed out that the narrative tradition clearly needed a person who was responsible for preserving the ancient tales, a minnuga man who was responsible for memorizing and passing along important traditions, narratives and myths. In von Friesen's formulation, above, the Rök stone's scald more than anyone else can be said to be worthy of the title pul, which possibly was the name of a role the scald played in certain ceremonial or traditional contexts (Wessén I958:76; Widmark I997:167ff. and literature cited therein; Arwill-Nordbladh 2007:58).

A number of strophes/verses begin with the repetitive Jag säger 'I speak/say/tell' and a simultaneous varied epic, which is characteristic of, for example, medieval ballads ( $c f$. Jansson I999:2 I 2). Along with the text's rhythmical poetics this gives indications that the Rök stone's epic should not be understood as meant for traditional reading - or for reading aloud - but for the specialized form of interpretation that makes use of linguistic rhythm, intonation and melody: melodious recital.

A formulation in "The Plaint of Oddrún" in The Poetic Edda may be interpreted in this manner (The Poetic Edda. Vol. II. Mythological Poems. Ed. ... by U. Dronke 1997:284):

... his harp I heard ... how the strings he struck, bestead full sore.

An indication of similar kind is given in the Beowulf poem (Beowulf. Transl. by M.Alexander, I973:I I 7; Sundqvist 2002a:I7 I, 2002b:I43): 
... the daring-in-battle would address the harp, the joy-wood, delighting; or deliver a reckoning both true and sad; or he would tell us the story of some wonderful adventure, valiant-hearted king.

Against such a background, the soft-sounding lyres with relatively distinct tones, such as those deposited in the burial boat at Sutton Hoo in the 620 s AD, have their natural explanation: an instrument that would support the pulse or rhythm of the presentation with some kind of ringing "inter-punctuation" consisting of whole or broken chords. Similar lyres were also deposited in the grave at Taplow around AD 600, the grave at Prittlewell in the 6oos AD, in the graves at Bergh Apton, and in Severinus Church in Cologne. They are also represented by the bronze bridge for six strings from Gerete, Fardhem parish, Gotland (SHM 34689), which Martin Rundkvist brought to my attention; the amber bridge for four strings from Broa, Halla parish, Gotland (SHM I0796); and the elk-horn bridge for five strings from Birka (SHM 5208:I634) (Bruce-Mitford I979:44ff; Tegnér I980; Gustafsson \& Vedin 2007:I97ff). The bronze bridge from Gerete is equipped with a thin bronze thread to secure the strings, which shows that the movement from their vibrations must have been very slight. The bridge from Broa was about I $5 \%$ higher and the bridge from Birka almost $70 \%$ higher than the one from Gerete.

Such string instruments definitely were not melodious, but were best used as a chiming support to an oral recitation - a melodrama. Altogether this may be used as a basis for the assumption that $p u l$ was a particular kind of story-teller or singer who used melodious recital as an interpretative form of expression.

\section{*RÖKSTAD (?)}

Where was the original place of the monument? Previous research has seen the earliest evidence for the parish name, de Røskyrc, from the year AD I2O2 as a direct reference to rauken, which means more or less 'the standing/raised stone' (Gustavson I99I:3). In some respects this seems to be a rather far-fetched explanation.

Something that looks intentional is the unidentified place-name with the prefix Rök-found among the oldest lands donated to the monastery Vreta kloster, which like the Rök stone is located in the province of Östergötland. Around the year AD I I70, a woman named Æstrid 
gave her daughter a dowry in the form of lands in Granstad, Tjällmo parish, and in *Rökstad (parish unknown). Other parishes appearing among the early land donations to the monastery are Slaka, close to Linköping, and Kimstad, close to Norrköping. As presented by Alf Ericsson in his cartographic account of donations to the monastery prior to the year I I 70 or so, a certain argument may be made for the location of this "Rökstad in Lysing hundred (Ahnlund I 945:3 I 8f; Gillingstam I948:26f; Ericsson 2007:I07ff; Fig. 38 and Tab.3).

Like Heda and Kumla, Rök has no village connected to the church. However, in the draft of the land surveyor Anders Börjesson's (Gadd) map from I639-4I (Signum Ra Dioa:4 If) a deviating pattern of ownership can be seen in the structure of lands adjacent to the church and vicarage. This partly includes an abandoned field and partly a field belonging to Millingstorp, which is a hint that the church property may be a construction remaining from an earlier settlement unit that disappeared already in the seventeenth century - "Rökstad (?) (Andersson I963; Brink I990b:34f; Johansson I 990:72ff; Kennerstedt I990:I 27f).

Considering the earliest spelling of the parish name from $\mathrm{AD}_{\mathrm{I}} 2 \mathrm{O2}$, de Røskyrc, one should consider that the place-name Rök may be a reductive construction of the Old Swedish *Røk/stadha/kirkia and comparable to the Gotlandic parish name Stenkyrka, which originally could have referred to the village or estate named Stenstugu: *Sten/stugu/kirkia (Kyhlberg I 99I:I I 5). Thus it would be a semantic analogy with, for example, the parish name of Rogsta (about I34 I in Rochstadum) in Hälsingland, which according to Brink can be traced back to an obsolete village name with the terrain-related prefix *rok 'higher ground or hill' (Andersson I 963:95ff; Brink I 990a:326ff and references cited therein; I990b:34; Wahlberg, M. (Ed). 2003:257 and photo 57).

\section{JÄTTINGSTAD}

As a consequence of the above-suggested interpretation of iatun as a heit $i$ for the monument itself, focus shifts to the place-name Jättingstad ( $1399 j$ joetunngsxstadhom), which is mentioned on the rune stone Ög I 32 at Heda Church (Östergötlands runinskrifter I 9 I 5:I 26f, Pl.XLIII).

In reference to von Friesen, Elias Wessén has commented on the derivation of the somewhat problematic first element of the placename (Wessén I958:54 note 2; cf. Jättendal in Hälsingland according to Brink I990a:289f with note 6; Johansson I990:73): 
(... more likely) nickname of a person. But the possibility that a mystical local tale of some giant who thus gave the village its name is perhaps not out of the question.

Except for Kumla, of the churches near Lake Tåkern it is possibly only Heda Church that is surrounded by an area with ancient monuments (Broberg I990:Fig. 2; Brink I990b:34). Five villages are located at the western, southern and eastern peripheries of this area. Heda parish holds a unique position with respect to the distribution of ancient monuments, which shows a strong spatial relationship to the parish territory! This pattern of burial monuments along the east, southeast and south boundaries of the parish, together with the agglomeration of burial monuments and mounds at the site of the church, should therefore be interpreted as an expression of some kind of ownership structure, at the center of which is the site of the church. A similar picture is evident in the distribution of runic inscriptions (Broberg I990:Fig. 2; Palm I990:Fig. 6, App. I). Somewhat less than two kilometers southwest of Heda lies Tuna (I374 in tunum), and east-southeast, at slightly more than one kilometer, lies Disevi/d (Brink I990b:38). About two kilometers south-southwest of Heda and one kilometer farther south from Tuna lies Jättingstad. The village of Tjugby is about two kilometers east-northeast of Heda. The first element in the place-name Tjugby is probably a thiudh (Vikstrand 200I:87f), which possibly signals the place of a local or regional assembly, a thing. Andersson has analyzed the written sources concerning thing places and their spatial situation, and he has suggested that a Tingsmaden ( I 682 Tingzma) under Frösäng $\mathrm{I}^{\mathrm{I}}$ south-southeast of Disevi/d could be related to the fifteenth-century thing place *Haraker (Andersson I965:28 Iff; Gustavson I99I:II). Altogether this indicates that the Tuna-Heda-Jättingstad area has held some form of unique position within the region.

The position of the scald and rune-master Sibbe in the legal society may have been linked (indirectly?) to the stone's supposed spatial connection to thing places. A possible early central place and the primary spot for the Rök stone in the Tuna-Heda-Jättingstad area can perhaps be seen by these contextual indices.

In association with Heda Church, there are peasant stories from more recent time telling of a giant. Perhaps this mythical tale emanated from the large rune stone, which could well have been commonly referred to as "the giant". In such an explanatory context, the place-name 
Jättingstad may be imagined as representing an important location in the Rök stone's creation. According to praxis, the estate or village in this case was given its name after the monument had been removed.

The Rök stone's supposedly prominent position in common tradition could explain why in the Iron Age/Middle Ages it was moved to Rök, perhaps in connection with the establishment of a thing place and/or because of the construction of the church in the first half of the twelfth century.

\section{CONCLUSIONS AND EPILOGUE}

The incentive for the monument ought to have been when Varin, probably a regional sovereign or lord, lost the son who would have been his rightful heir according to the patrilineal legal system of the time.

Varin commissioned an erfidrápa from Sibbe, who bore the exclusive epithet *viavari 'watchman of the sanctuaries' and who probably was a law-man. Sibbe tells us that he succeeded in (the feat of) carving this giant-like piece of rock while in his eighties. He asserts his mastery as scald and rune carver by twice calling himself 'the knowledgeable sorcerer', or in this context most likely the 'rune-magician', and through his narratives addresses future generations.

Varin's commission of an elegiac memorial poem to his deceased son was carried out in such an artistic way that the result is just as much a monument to the rune-master's literary refinement, literary competence and power of creating characters as it is a memorial to Vämod Varinsson.

In his learned introduction to Snorre's Edda, Björn Collinder maintains that Snorre's intentions were to provide future generations with a handbook of ancient mythology, courtly language, and traditional scaldic poetry along with an account of the ancient stylistic metrical verse. The former, says Collinder, became Snorre's testimony (Snorre's Edda ... I958:I9ff). A similar value perspective may be applied to the Rök stone and its maker. From Sibbe and his masterpiece there seems to be - via Snorre and his Edda - a thread of conceptual history and history of ideas that extends to Olof Rudbeck (d. I702), his magnum opus Atlantican, and the grandiose Latin inscription on his gravestone in Uppsala Cathedral, which in free translation says that the gravestone shows his mortality while the Atlantican shows his immortality. 


\section{Acknowledgement}

I am very grateful to Phyllis Anderson Ambrosiani for her exquisite translation and to Pål Andersson, Anders Carlsson, Helmer Gustavson, Lena Johansson, Magnus Källström and Thorgunn Snaedal for advice and assistance. Last, but not least, I want to express my gratitude to David Bruno for producing the photographs. 


\section{References}

Ahnlund, N. 1945. Vreta klosters äldsta donatorer. Historisk tidskrift. Sextiosjätte årgången. Pp. 30I-35I.

Andersson, Th. I963. Sockennamnen Hedheskirkia 'Heda' och Røskirkia 'Rök'. Namn och bygd: tidskrift för Nordisk Ortnamnsforskning. Femtioförsta årgången. Pp. 95-I I9.

- 1965. Svenska häradsnamn. Nomina Germanica - Arkiv för germansk namnforskning I4. Lund: Sahlgren, J. (Ed).

- 2006. Varin och Vamod - och Sibbe. In: Peterson, L., Strandberg, S. \& Williams, H. (Eds). Namn och runor: uppsalastudier i onomastik och runologi till Lennart Elmevik på 70 -årsdagen 2 februari 2006. Namn och samhälle I7. Pp. I-8. Uppsala.

Andrén, A. 2000. Re-reading Embodied Texts - an Interpretation of Rune-stones. In: Burström, M. \& Carlsson, A. (Eds). Current Swedish Archæeology 8. Pp. 7-32. Stockholm: The Swedish Archaeological Society.

Arwill-Nordbladh, E. 2007. Memory and Material Culture - the Rune-stone at Rök. In: Fransson, U. \& Svedin, M. \& Bergerbrant, S. \& Androshchuk, F.(Eds). Cultural interaction between east and west. Archaeology, artefacts and human contacts in northern Europe. Stockholm Studies in Archaeology 44. Pp. 56-60. Stockholm.

Beowulf: A Verse Translation. Alexander, M. (Trans.). Penguin Classics. Great Britain 1973 .

Boken om Ansgar. Rimbert: Ansgars liv. Översatt av Eva Odelman. Med kommentarer av A. Ekenberg, C. F. Hallencreutz, S. Helander, A. Härdelin \& E. Odelman. 1986. Stockholm: Proprius.

Brink, S. I990a. Sockenbildning och sockennamn. Studier i äldre territoriell indelning $i$ Norden. Vol. LVII. Studier till en svensk ortnamnsatlas I4. Andersson, Th. (Ed). Uppsala: Acta Academiæ Regiæ Gustavi Adolphi.

- I990b. Tåkernbygden. En bosättningsonomastisk studie. In: Dahlbäck. G. (Ed). I Heliga Birgittas trakter. Nitton uppsatser om medeltida sambälle och kultur $i$ Östergötland "västanstång". Pp.29-55. HSFR. Stockholm.

-2003 . Den förkristna muntliga kulturen i Norden: till frågan om det kollektiva minnet. Saga och Sed. Kungl. Gustav Adolfs akademiens årsbok. Pp. 7 I-8I. Uppsala.

Broberg, A. I990. Tåkernbygden. En arkeologisk bebyggelseanalys. In: Dahlbäck. G. (Ed.). I Heliga Birgittas trakter. Nitton uppsatser om medeltida sambälle och kultur i Östergötland "västanstång”. Pp. I I-27. HSFR. Stockholm.

Bruce-Mitford, R. 1979. The Sutton Hoo Ship Burial. A Handbook. 3rd ed. London: British Museum.

Den poetiska Eddan. Översättning av Björn Collinder. 3 rd ed. 1972. Uddevalla: Forum.

Elmevik, L. 2008. Runföljden uilinspat på Rökstenen. In: Wahlberg, M. \& Leibring, K. \& Nyström, S. (Eds). Ortnamnssällskapets i Uppsala årsskrift. Pp. I 5-23. Uppsala.

Ericsson, A. 2007. Attungen - ett medeltida fastighetsmått. En agrarhistorisk undersökning baserad på attungsbelägg i SDhk till år 1376 och Folke Dovrings kasuistik. Uppsala, Swedish University of Agricultural Sciences:Licentiate thesis.

von Friesen, O. I907. Rökstenen. Svenska Turistföreningens årsskrift I906. Pp. 42-55. Stockholm. 
- I920. Rökstenen: runstenen vid Röks kyrka Lysings härad Östergötland / läst och tydd av Otto von Friesen. Stockholm.

Fritzner, J. I 883-96. Ordbog over Det gamle norske Sprog. In: Arup S.D. \& Knudsen T. (Eds). Ordbog over Det gamle norske Sprog. Nytt uforandret opptryck av 2. udgave med et bind tillaegg og rettelser 1954 . Oslo: Den norske forlagsforening.

Gillingstam, H. I948. Ett nytt bidrag till kunskapen om Vreta klosters äldsta historia. Historisk tidskrift Sextioåttonde årgången. Pp. 26-29. Stockholm.

Grønvik, O. 2003. Der Rökstein: über die religiöse Bestimmung und das weltliche Shicksal eines Helden aus frühen Wikingerzeit. Osloer Beiträge zur Germanistik 33. Frankfurt am Main: Lang.

Gustafsson, N. B. \& Vedin, E. 2007. Ett strängstall i brons från Gerete i Fardhem sn på Gotland. Fornvännen. Pp. I97-I99. Stockholm: Kungl. Vitterhets historie och antikvitetsakademien.

Gustavson, H. I99I. Rökstenen. In: Richert, A. (Ed). Svenska Kulturminnen 23. Stockholm: Riksantikvarieämbetet.

Hallberg, P. I993. Snorri Sturluson - isländsk storman och historieskrivare. In: Dahlbäck. G. (Ed): Snorre Sturlasson och de isländska källorna till Sveriges historia. Fyra föreläsningar från ett symposium i Stockholm hösten I 988 . Sällskapet Runica et Mediævalia. Opuscula I. Pp. 43-63. Stockholm: Sällskapet Runica et Mediævalia.

Harris, J. 2007. Myth and meaning in the Rök inscription. Viking and Medieval Scandinavia 2. Pp. 45-109. Turnhout: Brepols.

Heimskringla. History of the kings of Norway by Snorre Sturlasson. Translation with introduction and notes by Lee M. Hollander. Austin, Texas, I964.

Hellberg, L.I979. Forn-Kalmar. Ortnamnen och stadens förhistoria. In: Hammarström, I. (Ed.). Kalmar stads historia, I. Kalmarområdets forntid och stadens äldsta utveckling. Tiden intill I 300 -talets mitt. Kalmar: Kulturnämnden.

Henriksson, G. 1995 Riksbloten och Uppsala högar. Tor. Tidskrift för nordisk fornkunskap I. Pp. 337-393. Uppsala universitet.

Holmbäck, Å. \& Wessén, E. 1979. Svenska landskapslagar tolkade och förklarade för nutidens svenskar. Fjärde serien: Skånelagen och Gutalagen. Uppsala: AWE/ Gebers.

Jansson, S.-B. 1999. Den levande balladen. Medeltida ballad i svensk tradition. Falun: Prisma.

Jansson, S.B.F. r977. Runinskrifter i Sverige. 2d ed. Uppsala: Almqvist \& Wiksell.

- I987. Runes in Sweden. Translation: Peter Foote. Photo: Bengt A. Lundberg. Stockholm: Almqvist \& Wiksell.

Johansson, Mats I990. Tåkernbygden. En bebyggelsehistorisk analys. In: Dahlbäck. G. (Ed.). I Heliga Birgittas trakter. Nitton uppsatser om medeltida sambälle och kultur $i$ Östergötland "västanstång". Pp. 57-77. Stockholm. Humanistisk-samhällsvetenskapliga forskningsrådet.

Jónsson, F. (Ed.) I93 I. Lexikon Poeticum Antiquxe Linguxe Septrentionalis. Ordbog over det norsk-islandske skjaldesprog oprindelig forfattet af Sveinbörn Egilsson. København: Det Kongelige Nordiske Oldskriftselskab.

Kennerstedt, L. I990. Östgötaslättens romanska kyrkor. En översikt. In: Dahlbäck. G. (Ed.). I Heliga Birgittas trakter. Nitton uppsatser om medeltida sambälle och kultur i Östergötland "västanstång". Pp.I I I-I32. Stockholm. Humanistisksamhällsvetenskapliga forskningsrådet.

Kyhlberg, O. I99г. Gotland mellan arkeologi och historia. Om det tidiga Gotland. Theses and Papers in Archaeology 4. Stockholm universitet. 
Lagman, S. I989. Till försvar för runristarnas ortografi. Runrön. Runologiska bidrag utgivna av Institutionen för nordiska språk vid Uppsala universitet, I. Projektet de vikingatida runinskrifternas kronologi. En presentation och några forskningsresultat. Pp. 27-37. Uppsala.

Lönnroth, L. I977. The Riddles of the Rök-Stone: a structural approach. Arkiv för nordisk filologi 92. Pp.I-57. Lund: C.W.K. Gleerup.

Meissner, R, I92 I. Die Kenningar der Skalden:ein Beitrag zur skaldischen Poetik. Rheinische Beiträge und Hülfsbücher zur germanischen Philologie und Volkskunde. Bonn \& Leipzig.

Nationalencyklopedien. Ett uppslagverk på vetenskaplig grund utarbetat på initiativ av statens kulturråd. Elfte Bandet I993. Höganäs: Bra Böcker.

Nordberg, A. 2006. Jul, disting och förkyrklig tideräkning: kalendrar och kalendariska riter i det förkristna Norden. Acta Academiae Regiae Gustavi Adolphi XCI. Uppsala: Kungl. Gustav Adolfs Akademien.

Norr, S. I998. To Rede and to Rown. Expressions of early Scandinavian Kingship in Written Sources. Occasional Papers in Archoeology I7. Uppsala universitet.

Degnbol, H. \& Jacobsen, B.C. \& Rode, E. \& Sanders, C. \& Helgadóttir.p. (Eds) I995. Ordbog over det norrøne prosasprog. Vol. I. København: Den arnamagnæanske kommission.

Palm, R. I990. Runinskrifterna i Östergötland "västanstång”. Ålderskriterier och kronologi. In: Dahlbäck. G. (Ed). Heliga Birgittas trakter. Nitton uppsatser om medeltida samhälle och kultur $i$ Östergötland "västanstång”. Pp.79-97. Stockholm. Humanistisk-samhällsvetenskapliga forskningsrådet.

- 2004. Vikingarnas språk 750-I I00. Falun: Norsteds.

The Poetic Edda. Translated by L.M. Hollander with an Introduction and Explanatory Notes. Second ed. University of Texas, Austin I962.

The Poetic Edda. Vol. 2. Mythological Poems/edited with translation, introduction and commentaries by Ursula Dronke I997. Oxford: Clarendon.

Price, N. 2002. The Viking Way. Religion and War in Late Iron Age Scandinavia. AUN. Vol. 3 I. Uppsala university.

Ralph, B. 2007. Rökstenen och språkhistorien. In: Elmevik, L. (Ed). Nya perspektiv inom nordisk språkhistoria. Föredrag hållna vid ett symposium $i$ Uppsala 20-22 januari 2006. Acta Academiae Regiae Gustavi Adolphi XCVII. Pp. I2 I-I 43. Uppsala: Kungl. Gustav Adolfs Akademien.

Salberger, E. I980. Oklunda-hällens runristningar. In: Salberger, E. (Ed). Östgötska runstudier. Scripta runica I. Pp. 3-23. Göteborg.

Snorres Edda. Övers. och inledning av Björn Collinder I958. Oskarshamn: Forum.

Solli, B. 2004. Det norrøne verdensbildet og ethos. Om kompleksitet, kjønn og kontradiksjoner. In: Andrén, A. \& Jennbert, K. \& Raudvere. C. (Eds). Ordning mot kaos - studier av nordisk förkristen kosmologi. Vägar till Midgård, 4. Pp. 253-287. Lund: Nordic Academic Press.

Strid, J.-P. 2005 . Ett forntida kultcentrum utanför Linköping. In: Kaliff. A. \& Tagesson, G. (Eds). Liunga. Kaupinga. Kulturhistoria och arkeologi i Linköpingsbygden. Riksantikvarieämbetet. Arkeologiska undersökningar. Skrifter, 60. Pp. I47I66. Linköping: Riksantikvarieämbetet.

Sundqvist, O. I998. Kultledare och kultfunktionärer i det forntida Skandinavien. In: Westerlund. D. (Ed.) Religioner i norr. Svensk religionshistorisk årsskrift 7. Göteborg: Svenska samfundet för religionshistorisk forskning.

- 2002a. Freyr's offspring. Rulers and religion in ancient Svea society. Acta Universitatis Upsaliensis. Historia Religionum 2 I. Uppsala university. 
- Sundqvist 2002b. Håkon den gode och den ritualiserade makten. In: Stausberg, M. \& Sundqvist; O. \& Svalastog, A.L. (Ed.) Riter och ritteorier. Religionshistoriska diskussioner. Teoretiska ansatser. Religionshistoriska rapporter från Uppsala I8. Uppsala universitet.

- 2007. Kultledare i fornskandinavisk religion. Occasional Papers in Archaeology 4I. Uppsala universitet.

Sävborg, D. I997 Sorg och elegi i Eddans hjältediktning. Stockholm Studies in History of Literature 36. Stockholms universitet.

Söderberg, S. 1905. Om djurornamentiken under folkvandringstiden. Antiqvarisk tidskrift för Sverige XI:3. Stockholm: Kungl. Vitterhets Historie och Antikvitetsakademien.

Tegnér, G. I980. Ljudredskap. Lyra. Musik. Vendeltid. Pp. 323, 326. Stockholm: Statens Historiska Museum.

Wahlberg, M. (Ed). 2003. Svenskt ortnamnslexikon (SOL), Utarbetat inom Språkoch folkminnesinstitutet och Institutionen för nordiska språk vid Uppsala universitet. Uppsala: Språk-och folkminnesinstitutet.

Vikstrand, P. 200I. Gudarnas platser. Förkristna sakrala ortnamn i Mälarlandskapen. In: Andersson, Th. (Ed.) Studier till en svensk ortnamnsatlas I7. Acta Academiæ Regice Gustavi Adolphi LXXVII. Uppsala: Kungl. Gustav Adolfs Akademien.

Wessén, E. 1958. Runstenen vid Röks kyrka. KVHAA Handlingar. Filologiskfilosofiska serien 5. Stockholm: Kungl. Vitterhets Historie och Antikvitets Akademien.

Widmark, G. I993. Varför ristade Varin runor? Tankar kring Rökstenens inskrift. Saga och Sed. Kungl. Gustav Adolfs akademiens arrsbok: annales Academiae Regiae Gustavi Adolphi I992. Pp. 25-44. Uppsala: Kungl. Gustav Adolfs akademien.

- I997. Tolkningen som social konstruktion. Rökstenens inskrift. In: Nyström, S. (Ed.). Runor och ABC. Elva föreläsningar från ett symposium i Stockholm våren 1995. Pp. I65-I75. Sällskapet Runica et Medoevalia. Opuscula 4. Stockholm: Sällskapet Runica et Mediævalia.

Winkler, A.-C. 2008. Silver för nattvard eller blot? - ett depåfynd från tiden mellan asatro och kristendom i Gamla Uppsala. Uppsala Universitet: Seminar Paper.

Östergötlands runinskrifter granskade och tolkade av Erik Brate. Andra häftet I 9 I 6. Stockholm: Stockholm:Almqvist \& Wiksell international. 